\title{
Long-term monitoring of a successful recovery program of Peregrine Falcons in Virginia
}

\author{
Bryan D. WatTs ${ }^{1 *}$, Mitchell A. ByrD ${ }^{1}$, Elizabeth K. MoJicA ${ }^{1,2}$, \\ Shawn M. PADGETT ${ }^{1}$, Sergio R. Harding ${ }^{3} \&$ Craig A. KoppiE ${ }^{4}$
}

Received: April 12, 2018 -Revised: August 10, 2018 -Accepted: December 12, 2018

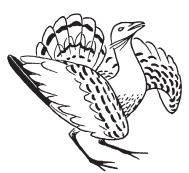

Watts, B. D., Byrd, M. A., Mojica, E. K., Padgett, S. M., Harding, S. R. \& Koppie, C. A. 2018. Recovery of Peregrine Falcons in Virginia. - Ornis Hungarica 26(2): 104-113. DOI: 10.1515/ orhu-2018-0018

Abstract The Peregrine Falcon (Falco peregrinus anatum) was believed to be extirpated as a breeding species in Virginia by the early 1960s. An aggressive restoration program was initiated in 1978 that involved the release of captive-reared birds totaling 115 on the Coastal Plain (1978-1985) and 127 in the Mountain physiographic region (1985-1993). The first occupied territory was established and the first breeding attempt was documented in 1979 and 1982, respectively. We have monitored the size, distribution, reproductive rate, and substrate use of the resulting breeding population (1979-2016). The population proceeded through an establishment phase (1979-1993) driven by releases with an average doubling time of 3.8 yrs to a consolidation phase (19942016) with an average doubling time of 23.1 yrs. The state supported 31 breeding pairs by 2016 . Per capita reproductive rates have increased significantly over the study period from 0.89 (1979-1993) to 1.86 (1994-2016). Average nesting success increased from $67.1 \%$ to $82.7 \%$ over the same period. Nesting attempts $(n=469)$ have been documented on dedicated peregrine towers $(52.1 \%)$, bridges $(26.1 \%)$, buildings $(4.1 \%)$, and various manmade structures $(13.0 \%)$ with only $4.7 \%$ documented on natural cliffs. The population appears to be self-sustaining with reproductive rates exceeding 1.5 young/pair every year since 1999. An ongoing management concern is that only $8.9 \%$ of known territories $(n=45)$ identified since introductions and $4.7 \%$ of documented breeding attempts $(n=469)$ have occurred within the historic mountain breeding range.

Keywords: Falco peregrinus anatum, restoration program, breeding population, reproductive rate

Összefoglalás Az 1960-as évek elejére úgy tünt, hogy a vándorsólyom (Falco peregrinus anatum) Virginia államból kipusztult, mint költő faj. 1978-ban elindult egy energikus visszatelepítési program, ami magában foglalta 115 fogságban felnevelt madár parti síkságon (1975-1985), és 127 madár hegyvidéki régióban (1985-1993) történő szabadon engedését. Az első territórium foglalást 1979-ben, az első költési kísérletet pedig 1982-ben írták le. Nyomon követtük a létrejött költőállomány méretét, elterjedését, költési sikerét és a fészekalapok típusát 1979-2016 között. Az állomány elöször egy alapítási fázison ment keresztül (1979-1993), amikor az állomány mérete 3,8 évenként duplázódott meg, majd a konszolidációs fázis következett (1994-2016), amikor az állomány duplázódási ideje 23,1 évre nőtt. 2016-ra az államban 31 költő pár volt. Az egy egyedre vetített szaporodási ráta jelentősen növekedett a vizsgált időszak alatt 0,89-röl (1979-1993) 1,86-ra (1994-2016). Az átlagos költési siker ugyanezen időszak alatt 67,1\%-ról 82,7\%-ra emelkedett. Költési kísérletek $(\mathrm{n}=469)$ tornyokon $(52,1 \%)$, hidakon $(26,1 \%)$, épületeken $(4,1 \%)$ és egyéb ember alkotta építményeken (13\%) voltak és csak 4,7\% volt természetes sziklákon. A populáció önfenntartónak bizonyult, 1999 óta minden évben 1,5 fióka/pár reprodukciós rátával. Továbbra is némi aggodalomra ad okot természetvédelmi kezelés szempontjából, hogy a visszatelepítés óta csupán a territóriumok 8,9\%-a és a költési kísérletek 4,7\%-a fordult elö az eredeti hegyvidéki költőterületeken.

Kulcsszavak: Falco peregrinus anatum, visszatelepítés, költőpopuláció, szaporodási siker 
${ }^{1}$ Center for Conservation Biology, College of William \& Mary and Virginia Commonwealth University, Williamsburg,VA 23187-8795, U.S.A., e-mail: bdwatt@wm.edu

${ }^{2}$ EDM International, Inc., 4001 Automation Way, Fort Collins, CO 80525, U.S.A.

${ }^{3}$ Virginia Department of Game and Inland Fisheries, 7870 Villa Park Drive, Suite 400, Henrico, VA 23228, U.S.A.

${ }^{4}$ Chesapeake Bay Field Office, U.S. Fish and Wildlife Service, Annapolis, MD 21401, U.S.A.

* corresponding author

\section{Introduction}

The historical population of Peregrine Falcons (Falco peregrinus anatum) in the eastern United States was estimated to contain approximately 350 breeding pairs, relied on open cliff faces and cut-banks for nesting, and was mostly confined to the Appalachian Mountains (Hickey 1942). The population experienced a precipitous decline throughout the 1950s (Hickey 1969) due to contaminant-induced reproductive suppression (Anderson \& Hickey 1972) and was believed to have been extirpated by the early 1960s (Berger et al. 1969). A retrospective assessment of the historic peregrine falcon population in Virginia identified 24 historical eyries in the Appalachian Mountains (Gabler 1983). Two additional nesting sites were documented on old osprey nests along the Virginia portion of the Delmarva Peninsula (Jones 1946).

The Peregrine Falcon was listed as endangered on the U.S. Federal List of Endangered and Threatened Wildlife (50 CFR 17.11-17.12) in June 1970. In 1975, the U.S. Fish and Wildlife Service appointed an Eastern Peregrine Falcon Recovery Team to develop and implement a recovery plan (Bollengier et al. 1979). In the absence of any residual breeding stock, one of the key components of the recovery strategy for the eastern population was the production and release of captive-reared falcons (Cade \& Fyfe 1978, Cade 2003). The breeding stock used for the captive program was of mixed heritage and contained individuals from non-indigenous subspecies (F. p. cassini, F. p. brookei, F. p. pealei, F. p. peregrinus, F. p. tundrius, F. p. macropus), as well as native F. p. anatum (Barclay \& Cade 1983). Within a relatively short period, a captive breeding program was established with enough capacity to sustain an aggressive release program (Barclay \& Cade 1983, Barclay 1988).

Between 1978 and 1993, 242 captive-reared falcons were released in Virginia including releases on the Coastal Plain (1978-1985) and in the Mountain physiographic region (19851993). Beginning in 2000, a translocation program was initiated in Virginia that has moved wild-reared birds from coastal territories to be hacked from mountain release sites. A large portion of the young used in this program have been produced on coastal bridges. Translocating birds from bridges to the mountains serves to release bridge workers from access restrictions imposed during the breeding season and helps to restore birds to their historic mountain breeding range. More than 250 birds have been moved since the inception of the program (Watts \& Watts 2016).

The successful establishment of a breeding population of peregrine falcons within Virginia has clearly contributed to the recovery of the broader eastern population (Enderson et al. 1995, Millsap et al. 1998) and to the eventual removal of the species from the U.S. Federal List of Endangered and Threatened Wildlife (Mesta 1999). The breeding population is well established and expanding. Here we describe the establishment, growth, breeding performance and nesting substrate use for this emerging population. 


\section{Study area}

We have monitored and managed peregrine falcons throughout the state of Virginia. Virginia extends from the Atlantic Ocean to the Appalachian Mountains and contains three physiographic regions including the Coastal Plain, Piedmont, and Mountains and Valleys. The Coastal Plain is bounded by the Atlantic Ocean to the east and the fall line to the west. The fall line is an erosional scarp where the metamorphic rocks of the Piedmont meet the sedimentary rocks of the Coastal Plain. Between these two boundaries the land slopes gently toward the fall line where it generally reaches an elevation of less than $80 \mathrm{~m}$. The Piedmont is bounded to the east by the fall line and to the west by the escarpment of the Blue Ridge Mountains. In the northern parts of the state the Piedmont is only $75 \mathrm{~km}$ wide but broadens to the south reaching nearly $300 \mathrm{~km}$ wide at the state line. The land slopes up to the west reaching $300 \mathrm{~m}$ in elevation at the escarpment. The Mountains and Valleys Region is bounded by the east slope of the Blue Ridge Mountains and the state line. The region supports many areas above $1,000 \mathrm{~m}$.

\section{Methods}

We determined the number of territorial pairs, clutch size, brood size, nesting success and productivity by regular monitoring. Between 1977 and 2009, we established more than 60 structures specifically for breeding peregrine falcons within the Coastal Plain of Virginia. An effort was made annually to check all existing structures on the Coastal Plain for evidence of resident falcons. An initial survey of breeding structures was conducted between 1 March and 30 April by foot, boat or plane. The number of adults attending sites and/or activity within nesting structures was recorded. Remaining sites on bridges or within urban areas were surveyed on the ground for occupation and breeding activity. In addition to specific peregrine structures, the area supports many man-made structures that may be suitable for nesting. Although some prominent man-made structures have been monitored by biologists over the years for peregrine activity many of these nesting sites were initially reported by the public. The mountains of Virginia support a considerable number of historic eyries (Gabler 1983) and cliffs suitable for nesting (Watts 2006). Many of these sites are remote and have been surveyed only periodically since reintroduction efforts were initiated in the mountains during the mid-1980s (Reynolds 2004, Watts 2006, Harding 2015).

We monitored sites known to be occupied during a given year 2-5 times from March through July to document breeding activity. We considered a breeding territory to be occupied if a pair of adult peregrines was resident during the breeding season. We considered nests to be active if eggs or young were detected and successful if $>1$ chick survived to banding age ( $>20 \mathrm{~d}$ ). We did not assess fledging rates in all years and believe that banding age is a good proxy for fledging since more than $95 \%$ of young banded survive to fledging age ( $\sim 45$ d). Furthermore, satellite tracking within this population has demonstrated that mortality occurs primarily in the first month post-fledging (Watts et al. 2011). We documented clutch size when possible and determined hatching rates for those eggs where fates could be determined. We report brood sizes for young that reached banding age. 
Colonization rates were expressed using the average time (in years) required for the nesting population (number of territorial pairs) to double in size $\left(\mathrm{t}_{\text {double }}\right)$. Doubling time was calculated using the growth equation $\mathrm{N}_{t}=\mathrm{N}_{0} \mathrm{e}^{\mathrm{rt}}$ where $\mathrm{N}_{\mathrm{t}}$ is the population size in 2016, $\mathrm{N}_{0}$ is the population size in 1979, e is the base of the natural logarithm, $r$ is the intrinsic rate of increase, and $t$ is the time interval between population estimates. With this configuration, $t_{\text {double }}=\ln (2) /$ r. Success rate was calculated for nesting attempts with known outcome (successful nests/nesting attempts with known outcome X 100). We used goodness-of-fit tests (G-test with Yates correction) to compare frequencies of categorical data. We used two-sample t-tests to compare means of continuous variables between categories. We tested distributions for possible deviation from normality using the Kolmogorov-Smirnov test and found no significant differences from expected normal distributions.

\section{Results}

From a single pair in 1979, the Virginia peregrine falcon population has grown to 31 pairs by 2016 with an average doubling time of 7.5 years (Figure 1). The establishment phase through 1993 (year when captive-reared releases were discontinued in the state) was particularly dramatic with an average doubling time of 3.8 years. The release of 242 birds

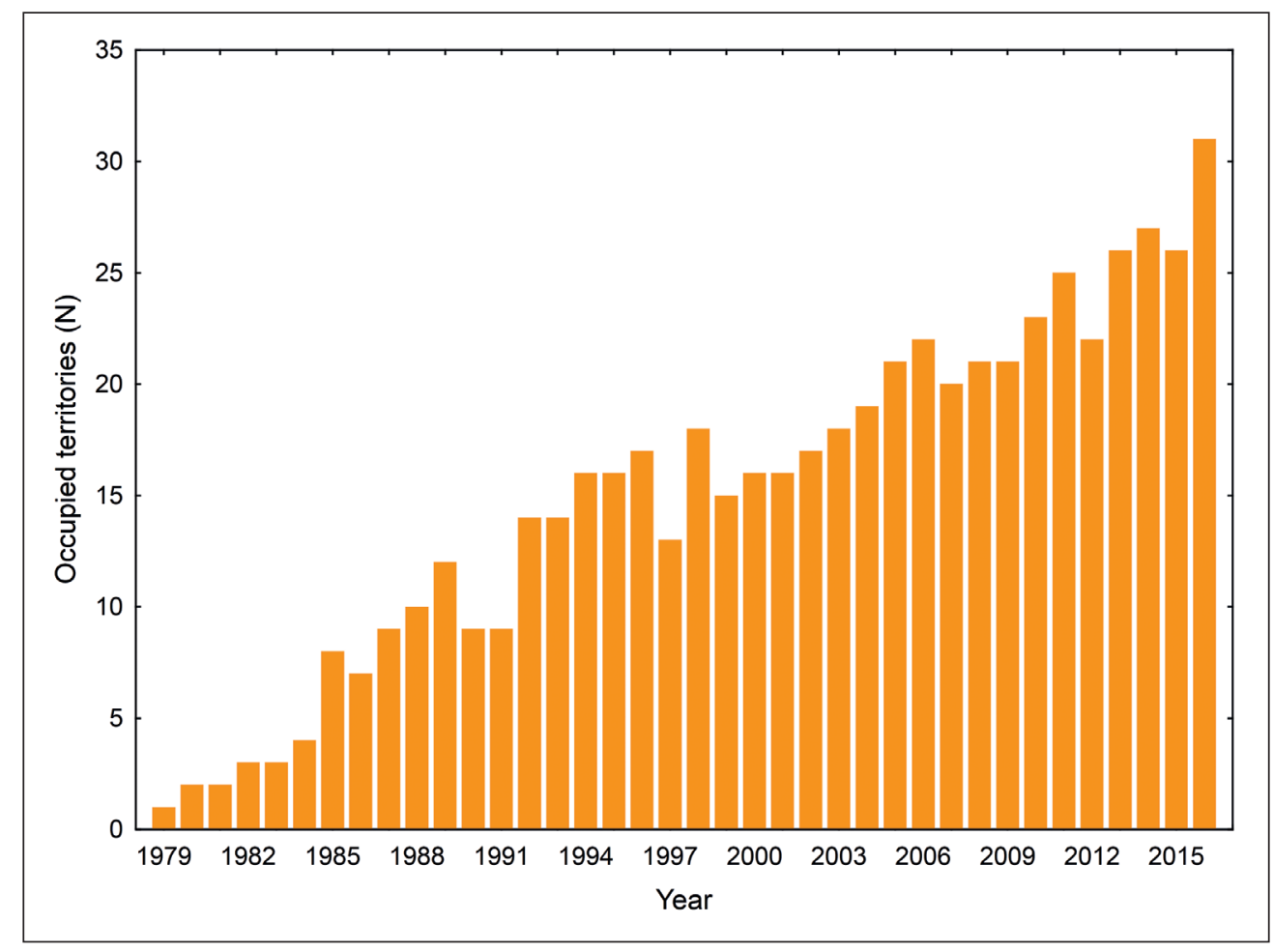

Figure 1. Size of the Peregrine Falcon breeding population in Virginia (1979-2016)

1. ábra A vándorsólyom költőpopulációjának mérete Virginia államban (1979-2016) 
resulted in the establishment of 16 territories in 15 years. Since 1993, the average doubling time has increased to 23.1 years as the population has become self-sustaining. Reproductive rates have exceeded 1.5 young/pair every year since 1999 .

During the study period, 469 breeding attempts were documented that produced 965 young. Average, annualized rates were $80.2 \pm 2.65 \%$ (mean \pm standard error) and $1.45 \pm$ 0.109 for breeding success and reproductive rate, respectively. Mean clutch and brood sizes were $3.6 \pm 0.04$ and $2.8 \pm 0.05$, respectively. Of 360 clutches where size was documented, 25 (7.0\%) contained 2 eggs, 93 (25.8\%) contained 3 eggs, 226 (62.8\%) contained 4 eggs and $16(4.4 \%)$ contained 5 eggs. For those eggs with known fate $(\mathrm{N}=1,256)$, hatching rate was $70.8 \%$. Of 346 clutches monitored, 55 (15.9\%) hatched no eggs, 132 (38.1\%) had partial hatch and $159(46.0 \%)$ hatched all eggs. Hatching rate varied annually from a low of $19 \%$ and a high of $100 \%$ with a mean of $72.0 \pm 3.26 \%$.

Per capita reproductive rates increased significantly over the study period $\left(\mathrm{R}^{2}=0.66, \mathrm{~F}\right.$ $[1,36]=68.4, \mathrm{p}<0.001)$. Reproductive rates averaged $0.89 \pm 0.088$ for the establishment period compared to $1.86 \pm 0.071$ for the consolidation period (Figure 2). The overall increase in per capita reproductive rate appears to have resulted from a significant increase in

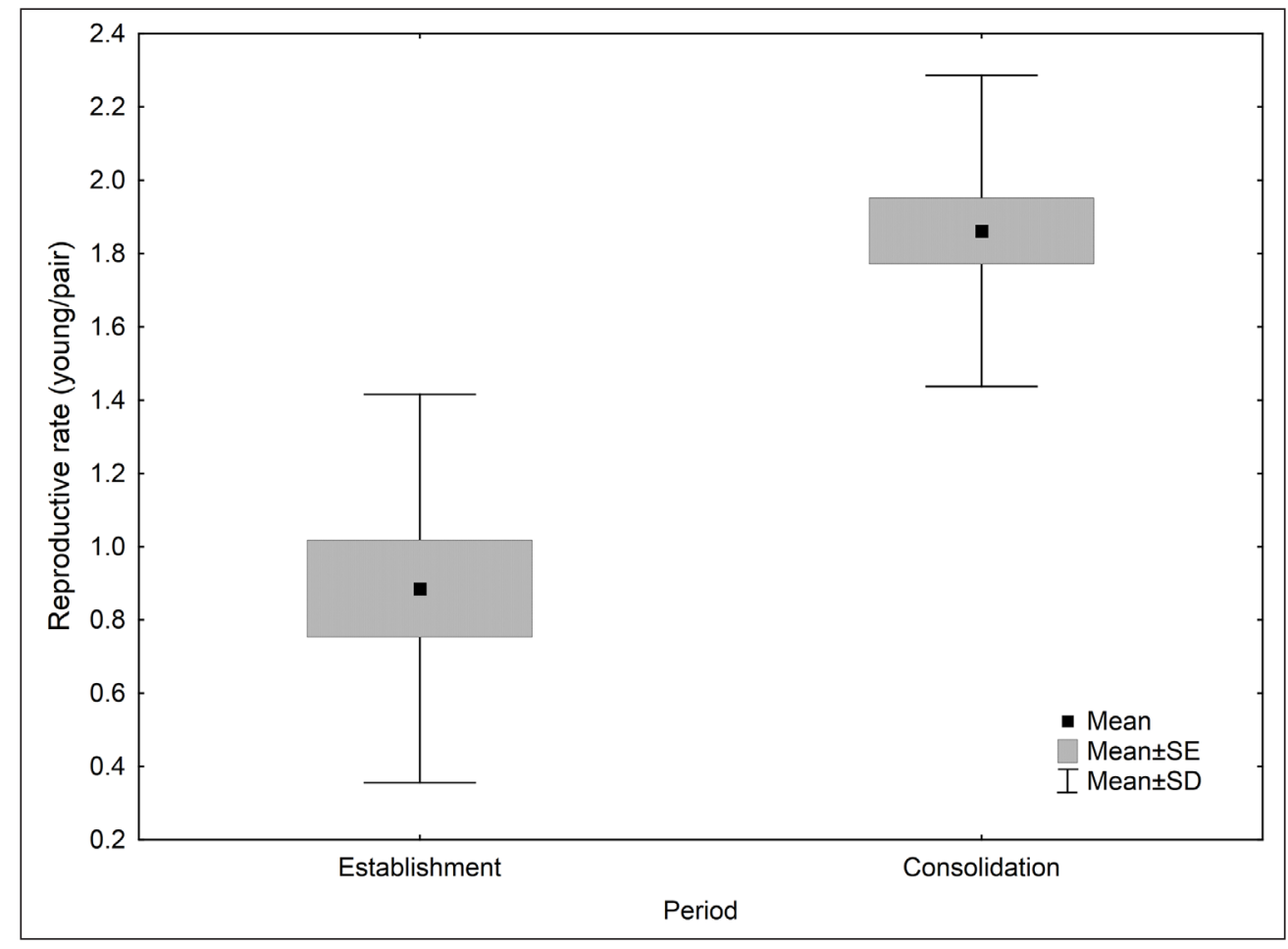

Figure 2. Comparison of Peregrine Falcon reproductive rates in Virginia between the establishment period (1979-1993) and the consolidation period (1994-2016). Rates were found to be significantly higher during the consolidation period

2. ábra A vándorsólyom reprodukciós rátáinak összehasonlítása Virginia államban a telepítési időszak (1979-1993) és a konszolidációs időszak (1994-2016) között. A konszolidációs időszakban a ráták szignifikánsan magasabbak voltak 
success rate (G-statistic with Yates Correction $=16.3, \mathrm{df}=1, \mathrm{p}<0.001)$ rather than average brood size (t-statistic $=0.72, \mathrm{p}>0.05)$. Success rate increased from $67.1 \%(47 / 70)$ for the establishment period (1979-1993) to 82.7\% (330/399) for the consolidation period (19942016). Brood size did not show the same pattern with $2.9 \pm 0.19$ young per successful nest during establishment and a similar value $(2.7 \pm 0.17)$ during consolidation.

We have identified 52 structures used for nesting within the study area. The most common structures were peregrine towers $(n=18)$, bridges $(n=12)$ and buildings $(n=5)$ that collectively represent $67.3 \%$ of the total. Less common structures have included 5 natural cliff faces, 3 abandoned shacks, 2 military ships, 2 active smoke stacks within coal-fired power plants, and 1 ground nest in a dune. One of the most unusual structures has been a pair that laid within the smoke box of a derelict brick chimney isolated in a marsh. The smoke box was only 3 feet above the marsh surface. Another pair was resident on a duck blind for two years but nesting was never confirmed. A pair nested on the ground within a dune and was successful 1 of 2 years (Boettcher \& Mojica 2016). Substrates used for nesting have diversified through time. Birds released from towers returned to establish breeding territories on towers during the early establishment period. The first bridge and building were not used until 1993 and 2003, respectively. In 1990, 83\% of known pairs were still nesting on towers. By 2016, towers accounted for less than $35 \%$ of substrates.

\section{Discussion}

The captive breeding and release program executed in Virginia as part of the federal recovery plan (Bollengier et al. 1979) has been successful in establishing a breeding population of peregrine falcons in the state. The growth rate of this population is comparable to those in other regions of North America that have included intensive reintroduction efforts (Enderson et al. 1995, Mesta 1999, Kauffman et al. 2003, Watts et al. 2015) with a clear establishment phase driven by releases and a more gradual consolidation phase driven by internal productivity. All the early breeding pairs resulted from released birds returning to hack towers. However, colonization of the historic mountain range has not been as rapid or as extensive as that observed on the outer Coastal Plain. A total of 115 birds were released on the coast between 1978 and 1985 and by 2016 the known breeding population had grown to 28 pairs. A total of 127 captive-reared birds were released in the mountains between 1985 and 1993 and the first occupied territory was documented in 1994. By 2016, relatively little additional establishment has been observed with the known population only including 2 pairs. This despite the fact that between 2000 and 2016 more than 260 wild-reared falcons have been translocated from the Coastal Plain and released in the mountains (Watts \& Watts 2016).

It remains unclear why breeding falcons have been slow to recolonize the historic mountain range in Virginia. The mountain region is large with a number of potential eyries that are remote and have been surveyed infrequently suggesting that there may exist pairs that are currently unknown. However, many historic eyries are accessible and have been monitored routinely. It seems highly unlikely that the number of unknown pairs in the mountains 
is significant or large enough to reach the historic population estimate of 25 breeding pairs. Many of the eyries on natural cliff sites that were documented in the early 1900s have been revegetated since that time and now appear to be of low site quality (Gabler 1983). Reproductive rates appear to support this claim. Of the breeding attempts in the mountains where outcomes are known, pairs produced 1.2 young per year.

Although we have not performed a population viability analysis (Wootton \& Bell 1992), both reproductive performance and the population trajectory suggest that the state-wide population is self-sustaining. Reproductive rates have become more stable over the past decade and have been maintained well above $1.25-1.50$ young per occupied territory, generally believed to support positive population growth rates (Grier \& Barclay 1988, Wootton \& Bell 1992). Releases of captive-reared birds during the establishment phase averaged just over 15 birds/yr. The population has exceeded this production every year since the last year of releases and in 2016 produced more than three times this number. Elevation in reproductive rates over the study period has resulted from increases in breeding success rather than in brood size. The underlying cause of this improvement is unclear but may be an artifact of a shifting age structure as the population has become established. Clum (1995) has shown that nestling survival increased throughout the lifespan of peregrines breeding in captivity. Mearns and Newton (1988) document an increase in both clutch and brood size with female age in Scotland.

It is possible that ongoing management activities may partially explain the increase in reproductive rates observed over time. We have used a range of management techniques for nesting peregrine falcons on artificial management structures to improve nesting success and to help stabilize nesting sites. Techniques have included adding gravel to structures used for nesting, installing nest trays, installing nest boxes and installing predator guards. The use of management structures has had a positive influence on breeding performance (Watts \& Watts 2017). Breeding success has increased significantly following the installation of management structures compared to before installation. In addition to an increase in breeding success, pairs nesting on management structures produced significantly more young birds compared to pairs nesting without such structures. Pairs nesting within boxes or on trays produced more than twice as many young compared to those that did not.

Even though the ancestry of the introduced population reflects a very large portion of the global range, the breeding population has successfully adapted to Virginia. Migratory status is mixed. Of 61 hatch-year birds tracked with satellite transmitters from Virginia (Watts et al. 2011), half migrated south to establish winter territories ranging from North Carolina to Colombia, South America. Remaining birds established winter territories within the mid-Atlantic region of the United States from Virginia through New York. Diet during the breeding season generally reflects the availability of bird species. Pairs nesting within inland locations feed primarily on Rock Pigeons (Columba livia) and migratory passerines (Long 2009). In contrast, migratory shorebirds are the dominant prey used by pairs nesting on the outer coast, representing $52 \%$ of the prey (Long 2009). Willets (Tringa semipalmata) and Short-billed Dowitchers (Limnodromus griseus) were taken in the highest numbers.

The population continues to be vulnerable to several mortality risks. Approximately half of the breeding pairs nest on bridges and buildings and are vulnerable to the array of factors associated with living in an urban landscape (Cade \& Bird 1990, Cade et al. 1996). 
Collisions with urban structures such as buildings, tower guy-wires, and transmission lines represented $40 \%$ of mortality identified during a tracking study in the state (Watts et al. 2011). Young from bridge nests frequently drown around fledging time when they are unable to fly back up to eyries due to the lack of updrafts. Exposure to some classes of contaminants such as flame retardants are believed to be higher within urban settings compared to the coastal areas, as indicated by higher concentrations within addled eggs (Morse 1993, Chen et al. 2008, 2010, Potter et al. 2009). By contrast, pairs along the outer coast appear to have higher exposure to legacy contaminants such as DDT and its metabolites, possibly due to their higher consumption of migratory shorebirds that winter in the tropics (Potter et al. 2009). However, eggshell-thinning rates relative to pre-DDT estimates have varied through time and space, making the general connection between contaminant exposure levels and spatial variation in reproductive rates difficult to assess within the population (Burns et al. 1994, Potter et al. 2009, Chen et al. 2010).

\section{Acknowledgements}

Funds were provided by the Virginia Department of Game and Inland Fisheries through a Federal Aid in Wildlife Restoration grant from the U.S. Fish and Wildlife Service and from The Center for Conservation Biology. We thank the many landowners who have allowed access to their properties for peregrine management and monitoring including the Virginia Department of Transportation, Virginia Department of Conservation and Recreation, Virginia Outdoors Foundation, Dominion Energy, the U.S. National Park Service, the U.S. Department of Defense, the U.S. Fish and Wildlife Service, the U.S. Forest Service, NASA and The Nature Conservancy. We thank the many biologists and citizens who have contributed to monitoring activities over the years including R. Boettcher, D. Bradshaw, R. Cashwell, W. Clark, K. Cline, R. Gubler, E. Long, R. Lukei, J. Marcell, R. Mayhorn, J. Mitchell, B. Paxton, R. Pickett, D. Raynes, A. Settles, F. Smith, T. Tabulenas, B. Truitt, K. Watson, M. Watts and A. Wilke. E. Lawler provided contracting assistance from the College of William and Mary.

\section{References}

Anderson, D. W. \& Hickey, J. J. 1972. Eggshell changes in certain North American birds. - Proceedings of the International Ornithological Congress 15: 514-540.

Barclay, J. H. 1988. Peregrine restoration in the eastern United States. - In: Cade, T. J., Enderson, J. H., Thelander, C. G. \& White, C. M. (eds.) Peregrine Falcon populations: their management and recovery.The Peregrine Fund, Inc., Boise, Idaho, pp. 549-558.

Barclay, J. H. \& Cade, T. J. 1983. Restoration of the Peregrine Falcon in the eastern United States. -Bird Conservation 1: 3-37.

Berger, D. D., Sindelar, C. R. Jr. \& Gamble, K. E. 1969. The status of breeding peregrines in the eastern United States. - In: Hickey, J. J. (ed.) Peregrine Falcon populations: their biology and decline. - University of Wisconsin Press, Madison, Wisconsin, pp. 165-173.

Bollengier, R. M. Jr., Baird, J., Brown, L. P., Cade, T. J., Edwards, M. G., Hagar, D. C., Halla, B. \& McCaffrey, E. 1979. Eastern Peregrine Falcon recovery plan. - U.S. Fish and Wildlife Service, Washington, DC.

Boettcher, R. \& Mojica, E. K. 2016. First record of Peregrine Falcon (Falco peregrinus) ground nesting activity on the U.S. Atlantic Coast. - Journal of Raptor Research 50: 313-315. DOI: 10.3356/JRR-15-72.1 
Burns, S. A., Jarman, W. M., Cade, T. J., Kiff, L. F. \& Watson, B. J. 1994. Organochlorines and eggshell thinning in Peregrine Falcon (Falco peregrinus) eggs from the eastern United States 1986-1988. - In: Meyburg B.-U. \& Chancellor R. D. (eds.) Raptor conservation today. - Pica Press, London, U.K., pp. $709-716$.

Cade, T. J. 2003. Starting the Peregrine Fund at Cornell University and eastern reintroduction. - In: Cade, T. J. \& Burnham, W. (eds.) Return of the peregrine: a North American saga of tenacity and teamwork. - The Peregrine Fund, Boise, Idaho, pp. 73-103.

Cade, T. J. \& Fyfe, R. W. 1978. What makes Peregrine Falcons breed in captivity. - In: Temple, S. A. (ed.) Endangered birds: management techniques for preserving threatened species. - University of Wisconsin Press, Madison, Wisconsin, pp. 251-262.

Cade, T. J. \& Bird, D. M. 1990. Peregrine Falcons (Falco peregrinus) nesting in an urban environment: a review. - Canadian Field-Naturalist 104: 209-218.

Cade, T. J., Martell, M., Redig, P., Septon, G. \& Tordoff, H. G. 1996. Peregrine Falcons in urban North America. - In: Bird, D. M., Varland, D. E. \& Negro, J. J. (eds.) Raptors in human landscapes: adaptations to built and cultivated environments. - Academic Press, San Diego, California, pp. 3-13.

Chen, D., La Guardia, M. J., Harvey, E., Amaral, M., Wohlfort, K. \& Hale, R. C. 2008. Polybrominated diphenyl ethers in Peregrine Falcon (Falco peregrinus) eggs from the Northeastern U.S. - Environmental Science and Technology 42: 7594-7600. DOI: 10.1021/es8010749

Chen, D., Hale, R. C., Watts, B. D., La Guardia, M. J., Harney, E. \& Mojica, E. K. 2010. Species-specific accumulation of polybrominated diphenyl ether flame retardants in birds of prey from the Chesapeake Bay region, USA. - Environmental Pollution 158: 1183-1889. DOI: 10.1016/j.envpol.2009.10.042

Clum, N. J. 1995. Effects of aging and mate retention on reproductive success of captive female Peregrine Falcons. - American Zoologist 35: 329-39. DOI: 10.1093/icb/35.4.329

Enderson, J. H., Heinrich, W., Kiff, L. \& White C. M. 1995. Population changes in North American peregrines. - Transactions of the North American Wildlife and Natural Resources Conference 60: 142-161.

Gabler, J. K. 1983. The Peregrine Falcon in Virginia: Survey of historic eyries and reintroduction effort. - Unpublished Master Thesis, College of William and Mary, Williamsburg, Virginia

Grier, J. W. \& Barclay, J. H. 1988. Dynamics of founder populations established by reintroduction. - In: Cade, T. J., Enderson, J. H., Thelander, C. G. \& White, C. M. (eds.) Peregrine Falcon populations: their management and recovery. The Peregrine Fund, Inc., Boise, Idaho, pp. 689-700.

Harding, S. R. 2015. The 2015 Surveys for Peregrine Falcons in Western Virginia. - Virginia Department of Game and Inland Fisheries, Bureau of Wildlife Resources, Richmond, Virginia

Hickey, J. J. 1942. Eastern population of the Duck Hawk. - Auk 59: 176-104.

Hickey, J. J. (ed.) 1969. Peregrine Falcon populations: their biology and decline. - University of Wisconsin Press, Madison, Wisconsin

Jones, F. M. 1946. Duck Hawks of eastern Virginia. - Auk 63: 592.

Kauffman, M. J., Frick, W. F. \& Linthicum, J. 2003. Estimation of habitat-specific demography and population growth for Peregrine Falcons in California. - Ecological Applications 13: 1802-1816. DOI: 10.1890/015324

Long, E. C. 2009. Prey utilization and energy demand of a breeding Peregrine Falcon (Falco peregrinus) population. - M.S. Thesis, College of William and Mary, Williamsburg, Virginia

Mesta, R. 1999. Final rule to remove the American Peregrine Falcon from the Federal List of Endangered and Threatened Wildlife, and to remove the similarity of appearance provision for free-flying peregrines in the conterminous United States. - Federal Register 64: 46542-46558.

Mearns, R. \& Newton, I. 1988. Factors affecting breeding success of peregrines in south Scotland. - Journal of Animal Ecology 57: 903-916. DOI: 10.2307/5100

Millsap, B. A., Kennedy, P. L., Byrd, M. A., Court, G., Enderson, J. H. \& Rosenfield, R. N. 1998. Review of the proposal to de-list the American Peregrine Falcon. - Wildlife Society Bulletin 26: 522-538.

Morse, N. J. 1993. Contaminants in Peregrine Falcon (Falco peregrinus) eggs from Virginia, Maryland, and West Virginia. - U.S. Fish and Wildlife Service report. Virginia Field Office, White Marsh, VA.

Potter, K. E., Watts, B. D., LaGuardia, M. J., Harvey, E. P. \& Hale, R. C. 2009. Polybrominated diphenyl ether flame retardants in Chesapeake Bay region, USA, Peregrine Falcon (Falco peregrinus) eggs: Urban/rural trends. - Environmental Toxicology and Chemistry 28: 973-981. DOI: 10.1897/08-350.1

Reynolds, R. 2004. The 2003 Virginia aerial mountain survey for nesting Peregrine Falcons. - Virginia Department of Game \& Inland Fisheries unpublished report, Richmond, Virginia 


\section{S. R. Harding \& C. A. Koppie}

Watts, B. D. 2006. An investigation of cliffs and cliff-nesting birds in the southern Appalachians with an emphasis on the Peregrine Falcon. - Center for Conservation Biology Technical Report Series, CCBTR-06-14. College of William and Mary, Williamsburg, VA.

Watts, B. D. \& Watts, M. U. 2016. Virginia peregrine falcon monitoring and management program: Year 2016 report. - Center for Conservation Biology, Technical Report Series, CCBTR-16-12. College of William and Mary \& Virginia Commonwealth University, Williamsburg, VA.

Watts, B. D. \& Watts, M. U. 2017. Investigation of breeding Peregrine Falcons on bridges. - Center for Conservation Biology, Technical Report Series, CCBTR-17-01. College of William and Mary \& Virginia Commonwealth University, Williamsburg, VA.

Watts, B. D., Padgett, S. M., Mojica, E. K. \& Paxton, B. J. 2011. FALCONTRAK: Final Report. - Center for Conservation Biology, Technical Report Series. CCBTR-11-07. College of William and Mary, Williamsburg, VA.

Watts, B. D., Clark, K. E., Koppie, C. A., Therres, G. D., Byrd, M. A. \& Bennett, K. A. 2015. Establishment and growth of the peregrine falcon breeding population within the mid-Atlantic Coastal Plain. - Journal of Raptor Research 49: 350-358. DOI: 10.3356/rapt-49-04-359-366.1

Wootton, J. T. \& Bell, D. A. 1992. A metapopulation model of the Peregrine Falcon in California: viability and management strategies. - Ecological Applications 2: 307-321. DOI: 10.2307/1941864

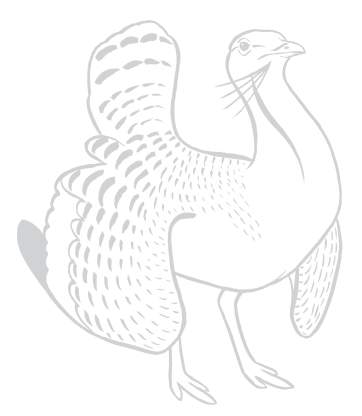

